\title{
Fluoride release by restorative materials before and after a topical application of fluoride gel
}

\section{Liberação de flúor por materiais restauradores antes e após a aplicação tópica de flúor em gel}

\author{
Denise Pedrini* \\ Alberto Carlos Botazzo Delbem** \\ Juliana Gomes Macedo de França*** \\ Thiago de Medeiros Machado***
}

\begin{abstract}
The release of fluoride from restorative materials (Vitremer, Ketac-Fil, Fuji II LC and Freedom) was evaluated during two 15-day periods, before and after a topical application of acidulated phosphate fluoride gel (APF). For each material, 6 specimens were made, which were immersed in $2 \mathrm{ml}$ of deionized water. The fluoride concentration dosages in the solutions were read at intervals of 24 hours for 15 days. After this period, the specimens of each material received treatment with APF gel for 4 minutes and the fluoride released was analyzed at 24-hour intervals during the following 15 days. The analysis of variance and the Tukey test $(\mathrm{p}<0.05)$ showed that the total mean fluoride released during the initial 15 days was greater for Vitremer and Ketac-Fil and lower for Fuji II LC and Freedom; and in the final 15 days there was a difference in release readings, with the greatest value for Vitremer, followed by Fuji II LC, Ketac-Fil and Freedom. The comparison of the results between the $1^{\text {st }}$ day and the $16^{\text {th }}$ day (after gel application) showed a greater fluoride release on the $16^{\text {th }}$ day for Vitremer, Fuji II LC and Freedom and was equal for Ketac-Fil. Although all the materials evaluated gained fluoride with the application of APF, the data suggest that the resin-modified ionomers are more efficient in releasing fluoride to the medium than the other materials.

DESCRIPTORS: Dental materials; Fluoride, analysis; Glass ionomer cements.
\end{abstract}

RESUMO: Avaliou-se a liberação de flúor de materiais restauradores (Vitremer, Ketac-Fil, Fuji II LC e Freedom) durante 2 períodos de 15 dias, antes e após a aplicação tópica de fluorfosfato acidulado (FFA). Foram confeccionados, para cada material, 6 corpos-de-prova que foram imersos em $2 \mathrm{ml}$ de água deionizada. As dosagens da concentração de flúor das soluções foram realizadas em intervalos de 24 horas durante 15 dias. Após esse período, os corpos-de-prova de cada material receberam tratamento com gel de FFA durante 4 minutos. O flúor liberado foi analisado em intervalos de 24 horas durante 15 dias. A análise de variância e o teste de Tukey $(\mathrm{p}<0,05)$ mostraram que a média total de flúor liberado durante os 15 dias iniciais foram maiores para o Vitremer e o Ketac-Fil e menores para o Fuji II LC e Freedom; e nos 15 dias finais apresentaram diferença de liberação, com maior valor para o Vitremer, seguido pelo Fuji II LC, Ketac-Fil e Freedom. A comparação dos resultados entre o $1^{\circ}$ dia e o $16^{\circ}$ dia (após aplicação do gel) mostrou uma maior liberação de flúor no $16^{\circ}$ para o Vitremer, Fuji II LC e Freedom e igual para o Ketac-Fil. Embora todos os materiais avaliados tenham ganhado flúor pela aplicação de fluorfosfato acidulado, os dados sugerem que os cimentos de ionômero de vidro modificados por resina são mais eficientes para liberar o flúor do que os outros materiais.

DESCRITORES: Materiais dentários; Flúor, análise; Cimentos de ionômeros de vidro.

\section{INTRODUCTION}

Restorative materials that release fluoride may prevent the development of secondary caries at the tooth/restoration interface ${ }^{22}$. The presence of fluoride around restorations with fluoridated materials reduces demineralization and increases remineralization ${ }^{12}$ and also acts diminishing the growth of Streptococcus mutans ${ }^{14}$. Among fluoridated materials, glass-ionomer cements deserve emphasis, as they are a potential source of fluoride release for prolonged periods of time ${ }^{10}$. The release behavior of conventional and resin-modified glass-ionomer cements, and polyacid-modified composite resins, varies according to the type of material and the composition of each commercial brand $^{5}$.

The capacity of some materials of recharging fluoride and releasing it again during a cariogenic challenge $^{10}$ is a factor to be considered. Studies show that conventional and resin-modified glass-ionomer cements, and polyacid-modified

*PhD, Department of Surgery and Integrated Clinic; **PhD, Department of Public Health and Pediatric Dentistry; ***Undergraduate Students - School of Dentistry of Araçatuba, São Paulo State University. 
Pedrini D, Delbem ACB, França JGM de, Machado T de M. Fluoride release by restorative materials before and after a topical application of fluoride gel. Pesqui Odontol Bras 2003;17(2):137-41.

composite resins are able to recharge fluoride from dentifrices, fluoridated solutions and gels $^{10,18,20,23}$ and to work as a reservoir of this element, allowing it to be constantly released and maintaining its anticariogenic properties in the long term.

However, in the literature, the effect of a topical application of acidulated phosphate fluoride gel (APF) is not well defined, since the regimes for applying the product make it difficult to evaluate its recharging properties ${ }^{2,4,23}$. An important factor in these researches is that the gels were applied da ily $y^{2,4,23}$ and this does not allow one to check what is being released to the environment, whether it is the fluoride adsorbed to the surface or that incorporated to the material matrix. Thus it would be interesting to make a daily observation of whether an application of APF is capable of promoting fluoride recharge and release in restorative materials.

\section{MATERIALS AND METHODS}

The restorative materials tested were: conventional glass-ionomer cement (C-GIC) Ketac-Fil (3M Espc, St. Paul, USA), resin-modified glass-ionomer cements (RM-GIC) Vitremer (3M Espe, St. Paul, USA) and Fuji II LC (GC Corporation, Tokyo, Japan) and polyacid-modified composite resin (PM-CR) Freedom (SDI, Bayswater, Australia). For each material 6 specimens were made, $5 \mathrm{~mm}$ in diameter and $2 \mathrm{~mm}$ in thickness, amounting to a surface area of $0.71 \mathrm{~cm}^{2}$. When the specimens were being prepared, the end of a $0.25 \mathrm{~mm}$ diameter stainless steel thread was inserted to facilitate their manipulation afterwards. For the materials Vitremer, Fuji II LC and Freedom, light-polymerization (Ultralux - Dabi Atlante, Ribeirão Preto, Brazil) with light intensity ${ }^{16}$ of $500 \mathrm{~mW} / \mathrm{cm}^{2}$ was carried out on one of the surfaces for a period of 40 seconds.

Each specimen was placed in a polystyrene tube with a cap, containing $2 \mathrm{ml}$ of deionized water, and was left to agitate ${ }^{5}$ at room temperature for 24 hours. An equal volume of TISAB II (acetate buffer $1.0 \mathrm{M}, \mathrm{pH} 5.0$, containing $\mathrm{NaCl} 1.0 \mathrm{M}$ and 1,2 -cyclohexanediaminetetraacetic $0.4 \%$ ) was added to the tubes. The specimens were washed with a deionized water spray, dried with absorbent paper and transferred to new tubes containing $2 \mathrm{ml}$ of deionized water.

After this period of 15 days repeating these cycles, the specimens of each material were treated with APF gel containing $1.23 \%$ fluoride ions, at pH 3.6 to 3.9 (Nupro - Dentsply, Petrópolis, Brazil) for 4 minutes. When the time had elapsed, the ex- cess gel was vigorously washed off for 30 seconds under deionized water, the specimens were dried with absorbent paper and immersed in the tubes containing $2 \mathrm{ml}$ of deionized water. From then on, they remained in tubes with deionized water, being agitated for 24-hour periods for 15 days, according to the above-mentioned method.

The solutions collected daily were identified and stored in polystyrene tubes at $4^{\circ} \mathrm{C}$ for the released fluoride to be determined later. The solutions of days $1,2,3,4,5,7,9,11,13,15,16,17,18,19$, $20,22,24,26,28$ and 30 were stored, and the others were ignored, as this period had already reached an almost constant level, and could be estimated $^{6}$.

Fluoride release was measured using a fluoride-specific electrode (Orion 9609-BN, Orion Research, Inc., Beverly, USA) connected to a digital ion-analyzer (Orion 720A, Orion 9609-BN, Orion Research, Inc., Beverly, USA), previously calibrated with standard solutions of 0.0625 to 1 or 1 to $16 \mu \mathrm{g} \mathrm{F}^{-} / \mathrm{ml}$ in TISAB II, and expressed in $\mu \mathrm{g}$ $\mathrm{F}^{-} / \mathrm{cm}^{2}$.

Statistical analysis showed the data to be heterogeneous, and transformation by means of the cube root was necessary. The analysis of variance was done considering the factors material and time, and the interaction, followed by the Tukey test. Student's paired $t$-test was used to compare fluoride release before and after APF application. For statistical analysis the software GMC version 9.0 was used and the significance level was established at 5\%.

\section{RESULTS}

The result of the analysis of variance showed significance for the factor material $(p=0.0001)$ and time $(\mathrm{p}=0.0001)$ and the interaction material versus time $(\mathrm{p}=0.0001)$. The results for the restorative materials (Table 1) indicate that the mean fluoride release in the 15 days, before the topical application of APF, was equal between Vitremer and Ketac-Fil. However, they differed statistically from Fuji II LC and Freedom, which showed a significant difference between each other. After the application, during the last 15 days of the experiment, the mean of fluoride release was significant, being greater for Vitremer, followed by Fuji II LC, Ketac-Fil and Freedom. These results were similar when the fluoride release means for the 30 days of the experiment were analyzed. Fluoride release after the application of the topical gel was shown to be greater for Vitremer and Fuji II LC when compa- 
Pedrini D, Delbem ACB, França JGM de, Machado T de M. Fluoride release by restorative materials before and after a topical application of fluoride gel. Pesqui Odontol Bras 2003;17(2):137-41.

TABLE 1 - Transformed sampling values (means $\pm S D, n=6$ ) of fluoride release for restorative materials.

\begin{tabular}{c|c|c|c}
\hline \hline Material & Before APF & After APF & Means \\
\hline Vitremer & A $1.30 \pm 0.02 \mathrm{a}$ & B $1.57 \pm 0.02 \mathrm{a}$ & $1.44 \pm 0.42 \mathrm{a}$ \\
\hline Ketac-Fil & A $1.35 \pm 0.02 \mathrm{a}$ & B $1.18 \pm 0.01 \mathrm{~b}$ & $1.26 \pm 0.46 \mathrm{~b}$ \\
\hline Fuji II LC & A $1.01 \pm 0.01 \mathrm{~b}$ & B $1.27 \pm 0.03 \mathrm{c}$ & $1.14 \pm 0.37 \mathrm{c}$ \\
\hline Freedom & A $0.69 \pm 0.04 \mathrm{c}$ & A $0.65 \pm 0.03 \mathrm{~d}$ & $0.67 \pm 0.38 \mathrm{~d}$ \\
\hline \hline
\end{tabular}

$\mathrm{APF}=$ acidulated phosphate fluoride. Means followed by distinct letters differ statistically at 5\%. Capital letters show difference between and after APF treatment for each material, and lower case between materials.

red with the first 15 days. For Ketac-Fil the result was the opposite and for Freedom, there was no difference between the fluoride release before and after gel application (Table 1).

Graph 1 illustrates the transformed values of the restorative materials fluoride release during the time of the experiment. Greater fluoride release $(\mathrm{p}<0.05)$ was found on the $1^{\text {st }}$ day for Ketac-Fil followed by Vitremer, Fuji II LC and Freedom, with a decrease over the course of time in the initial 15 days. On the $16^{\text {th }}$ day, after the acidulated gel application, there was a greater fluoride release, showing a significant difference when compared to the $1^{\text {st }}$ day for each material, with the exception of Ketac-Fil, which showed a similar value $(\mathrm{p}>0.05)$. When the fluoride release was compared among the materials on the $16^{\text {th }}$ day, a greater release was noted for Vitremer, followed by Ketac-Fil and Fuji II LC, which were statistically similar, and Freedom, which was different from the rest. Vitremer and Fuji II LC showed a greater fluoride release over the course of time in the last 15 days, when compared to the initial 15 days $(p<0.05)$. Ketac-Fil and Freedom showed fluoride release with a similar tendency between the two periods.

\section{DISCUSSION}

Dental caries prevention through the use of fluoride in its different forms of application has been the object of several studies. As the constant presence of fluoride plays an important role in that prevention, the success of topical treatments ${ }^{8}$ depends on the formation of fluoride reserves capable of releasing ions for prolonged periods of time. Therefore, the fluoride recharge in restorative materials provides a potential fluoride reserve for release in the oral environment.

Before the topical application of APF (Table 1), the results of this study indicated a greater fluoride release for Vitremer and Ketac-Fil, with no statistical difference between them. Momoi, McCabe ${ }^{17}$ (1993) and Tenuta et al. ${ }^{21}$ (1997) showed that there was no significant difference between C-GICs and

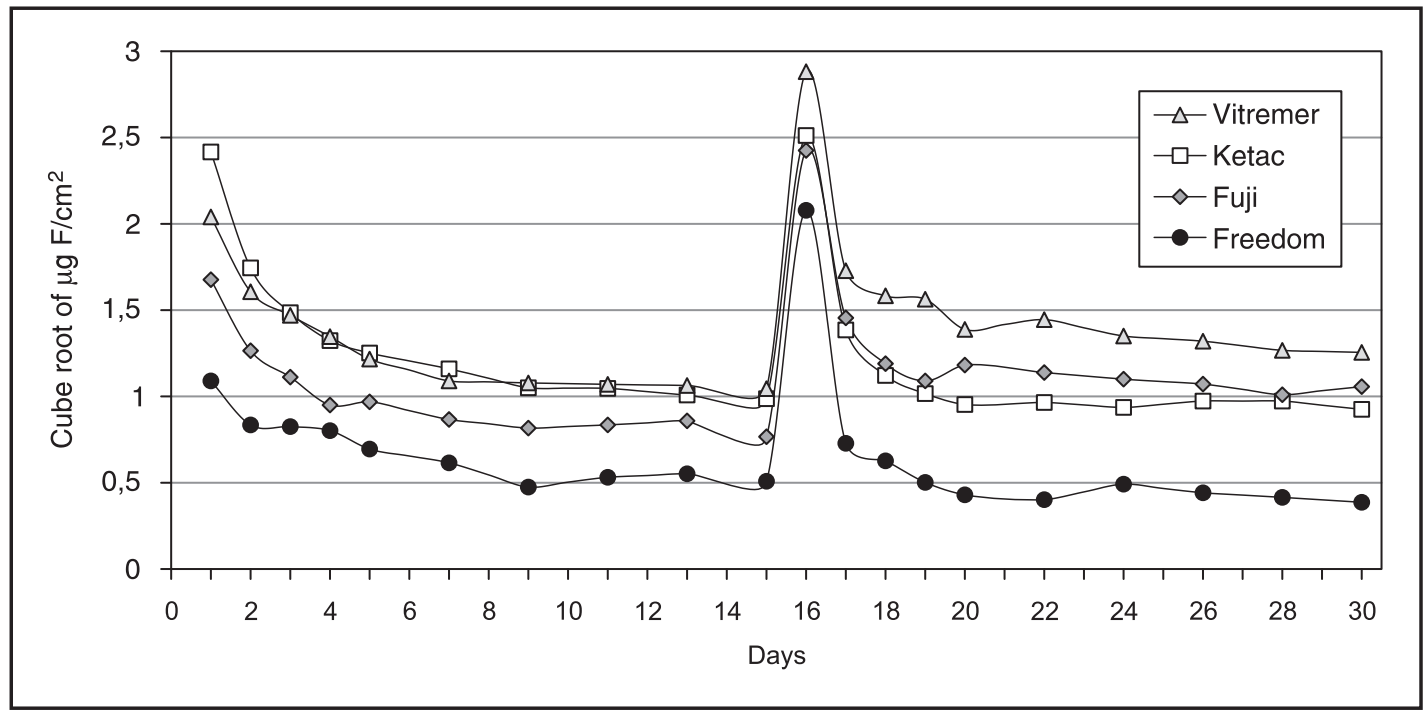

GRAPH 1 - Mean transformed values $(\mathrm{n}=6)$ of fluoride release in the course of time for each material. 
Pedrini D, Delbem ACB, França JGM de, Machado T de M. Fluoride release by restorative materials before and after a topical application of fluoride gel. Pesqui Odontol Bras 2003;17(2):137-41.

RM-GICs. However, the results showed a greater release for C-GIC (Ketac-Fil) when compared to the other RM-GIC (Fuji II LC). Costa et al. ${ }^{8}$ (1995), Carvalho, Cury ${ }^{5}$ (1998) and Bertacchini et al. ${ }^{3}$ (1999) observed better results for C-GIC than for RM-GIC. Aboush, Torabzadeh ${ }^{1}$ (1998), however, observed that the RM-GICs released more fluoride than did the C-GICs. C-GICs and RM-GICs show various behaviors, mainly, as a result of the difference in composition $^{11}$, diffusion of the fluoride ion through the material ${ }^{13}$ and difference in surface energy ${ }^{9,15}$. Other factors, like porosity and the powder: liquid ratio $^{9,15}$, as well as the materials' solubility ${ }^{3}$, may alter fluoride release. Momoi, $\mathrm{McCabe}^{17}$ (1993) emphasized that the type and amount of resin used for the photochemical polymerization reaction may affect the rate of release. One possible explanation is that the HEMA absorbs sufficient water to enable diffusion of the fluoride ions which may otherwise be firmly encapsulated within the polyacrylate matrix ${ }^{17}$. PM-CR (Freedom) showed the lowest values when compared to the other materials, indicating that the addition of polyacids to its composition did not favor the release potential for this material ${ }^{1,8}$.

Generally speaking, irrespective of the material, a marked fluoride release occurred in the first 24 hours, followed by an accentuated drop and the tendency to stabilize with the passage of time (Graph 1), being in agreement with the literatur $\mathrm{re}^{1,7,8,11,21}$. The greatest release observed in the initial periods after the mix may be explained by the fact that the glass-ionomer cement setting reaction is processed in a gradual manner within a time of approximately 12 to 24 hours $^{7}$. Thus, there is great ionic movement, facilitating the release of ionically active elements, fluoride being among them.

The topical application of fluoridated gel promotes a greater fluoride release as of the $16^{\text {th }}$ day for RM-GICs, the largest being for Vitremer (Graph 1). This recharge provides a greater fluoride release for the RM-GICs in the last 15 days when compared to the first 15 days. For C-GIC and PM-CR the recharge did not cause an increase in fluoride release when the two experimental periods are observed (Table 1 and Graph 1). According to Preston et $a{ }^{18}$ (1999), the exact mechanism of fluoride recharge is unknown. However, factors like the permeability of the material, the form and concentra- tion of fluoride used may be involved in the process.

The recharge and additional release of fluoride by the restorative materials were not due to contamination by fluoride gel remains, as differences occurred between the materials on the $16^{\text {th }}$ day (Graph 1), and the RM-GIC showed greater release levels after APF application, being maintained in the course of time (Table 1 and Graph 1). This may be explained by a diffusion of fluoride into the matrix of these materials ${ }^{20}$. But this did not occur with Freedom, which may indicate only an adsorption of fluoride, culminating in the return to values similar to those shown before the specimens were immersed in acidulated gel (Table 1 and Graph 1). The erosion caused by APF in the material may also contribute to the increase of fluoride release ${ }^{23}$. Theoretically, the C-GIC would be more affected; nonetheless, it did not show a greater fluoride release on the $16^{\text {th }}$ day when compared to the $1^{\text {st }}$. Addittionally, the C-GIC showed a lower fluoride release during the last days in relation to the days that preceded the gel application.

The clinical use of restorative materials that release fluoride is relevant, mainly in patients at risk of or with caries activity ${ }^{19}$. Our results indicate a greater fluoride release for the resin-modified glass-ionomer cements after APF application. However, the data of this study do not show whether this property would contribute towards the reduction of caries activity. For this, caries development tests are necessary to check whether this greater fluoride release would have any influence on the de-remineralization process.

\section{CONCLUSIONS}

Although all the materials evaluated gained fluoride after APF application, the data suggest that the resin-modified ionomers are more efficient at releasing fluoride to the medium than the other materials.

\section{ACKNOWLEDGEMENTS}

The authors thank the FAPESP agency for granting the scientific initiation scholarship (Process no. 00/00025-3), and the manufacturers 3M do Brasil and SDI for donating the materials used. 
Pedrini D, Delbem ACB, França JGM de, Machado T de M. Fluoride release by restorative materials before and after a topical application of fluoride gel. Pesqui Odontol Bras 2003;17(2):137-41.

\section{REFERENCES}

1. Aboush YEY, Torabzadeh H. Fluoride release from tooth-colored restorative materials: a 12 -month report. J Can Dent Assoc 1998;64:561-4, 568.

2. Azevedo AAC, Myaki SI, Rodrigues CRMD, Rodrigues Filho LE, Ando T. Liberação de flúor de selantes antes e após aplicação tópica de gel fluoretado. Rev Paul Odontol 2001;23:26-31.

3. Bertacchini SM, Abate PF, Blank A, Baglieto MF, Macchi RL. Solubility and fluoride release in ionomers and compomers. Quintessence Int 1999;30:193-7.

4. Bilgin Z, Ozalp N. Fluoride release from three different types of glass ionomer cements after exposure to NaF solution and APF gel. J Clin Pediatr Dent 1998;22:237-41.

5. Carvalho AS, Cury JA. Liberação de flúor de materiais restauradores. Rev Odontol Univ São Paulo 1998;12:367-73.

6. Carvalho AS, Cury JA. Fluoride release from some dental materials in different solutions. Oper Dent 1999;24:14-9.

7. Carvalho RM, Navarro MFL, Albuquerque MVP, Pinheiro CE. Padrão de liberação de flúor de cimentos odontológicos. RGO 1990;38:346-8.

8. Costa B, Rosa OPS, Carvalho RM, Bijella, MFTB. Estudo comparativo da liberação de flúor de materiais dentários restauradores. Rev Odontol Univ São Paulo 1995;9:279-84

9. Cranfield M, Kuhn AT, Winter GB. Factors relating to the rate of fluoride-ion release from glass ionomer cement. J Dent 1982;10:333-41.

10. Creanor SL, Carruthers LMC, Saunders WP, Strang R, Foye RH. Fluoride uptake and release characteristics of glass ionomer cements. Caries Res 1994;28:322-8.

11. DeSchepper EJ, Berry III EA, Cailleteau JG, Tate WH. A comparative study of fluoride release from glass-ionomer cements. Quintessence Int 1991;22:215-20.

12. Forss H, Seppä L. Prevention of enamel demineralization adjacent to glass ionomer filling materials. Scand J Dent Res 1990;98:173-8.
13. Forsten L. Fluoride release from a glass ionomer cement. Scand J Dent Res 1977;85:503-4.

14. Friedl KH, Schmalz G, Hiller KA, Shams M. Resin-modified glass ionomer cements: fluoride release and influence on Streptococcus mutans growth. Eur J Oral Sci 1997;105:81-5.

15. Maldonado A, Swartz ML, Phillips RW. An in vitro study of certain properties of a glass ionomer cement. J Am Dent Assoc 1978;96:785-91.

16. Martins F, Delbem ACB, Santos LRA, Soares HLO, Martins EOB. Microdureza de resinas em função da cor e luz halógena. Pesqui Odontol Bras 2002;16:246-50.

17. Momoi Y, McCabe JF. Fluoride release from light-activated glass ionomer restorative cements. Dent Mater 1993;9:151-4.

18. Preston AJ, Higham SM, Agalamanyi EA, Mair LH. Fluoride recharge of aesthetic dental materials. J Oral Rehabil 1999;26:936-40.

19. Serra MC, Rodrigues Jr AL. Potencial cariostático de materiais restauradores contendo flúor. Rev Assoc Paul Cir Dent 1998;52:359-64.

20. Takahashi K, Emilson CG, Birkhed D. Fluoride release in vitro from various glass ionomer cements and resin composites after exposure to $\mathrm{NaF}$ solutions. Dent Mater 1993;9:350-4.

21. Tenuta LMA, Pascotto RC, Navarro MFL, Francischone CE. Liberação de flúor de quatro cimentos de ionômero de vidro restauradores. Rev Odontol Univ São Paulo 1997;11:249-53.

22. Torii $\mathrm{Y}$, Itota $\mathrm{T}$, Okamoto $\mathrm{M}$, Nakabo $\mathrm{S}$, Nagamine $\mathrm{M}$, Inoue $\mathrm{K}$. Inhibition of artificial secondary caries in root by fluoride releasing restorative materials. Oper Dent 2001;26:36-43.

23. Yip HK, Smales RJ. Fluoride release and uptake by aged resin-modified glass ionomers and a polyacid-modified resin composite. Int Dent J 1999;49:217-25. 